A Journal of Culture, English Language, Teaching \& Literature ISSN 1414-3320 (Print), ISSN 2502-4914 (Online)

Vol. 19 No.2; December 2019

Copyright () Soegijapranata Catholic University, Indonesia

Emotional, Behavioral and Cognitive Engagement in Language Learning: The Experience of the Successful Learners

${ }^{1}$ Mister Gidion Maru and ${ }^{2}$ Christin Natalia Pajow

${ }^{1}$ English Education Department, Faculty of Languages and Arts, Universitas Negeri Manado, Indonesia

${ }^{2}$ Post Graduate Program, Universitas Negeri Manado, Indonesia

email: ${ }^{1}$ mrgidionmaru@unima.ac.id; ${ }^{2}$ christyn.pajow@yahoo.com

Received: 19-09-2017 Accepted: 20-09-2019 Published: 8-12-2019 


\title{
Emotional, Behavioral and Cognitive Engagement in Language Learning: The Experience of the Successful Learners
}

\author{
${ }^{1}$ Mister Gidion Maru and ${ }^{2}$ Christin Natalia Pajow \\ mrgidionmaru@unima.ac.id; christyn.pajow@yahoo.com \\ ${ }^{1}$ English Education Department, Faculty of Languages and \\ Arts, Universitas Negeri Manado, Indonesia \\ ${ }^{2}$ Post Graduate Program, Universitas Negeri Manado, \\ Indonesia
}

\begin{abstract}
This study aims at investigating and portraying learners' engagement with language in the learning process. It further shares the influence of the engagement upon the success of language acquisition. This study is methodologically qualitative. The semi-structured interview is implemented based upon the attempts to elaborate seven main questions and several follow-up questions. The respondents are from Manado, North Sulawesi. They are learners whose score above 500 in TOEFL ITP or equivalence to IELTS above 6.0 as the qualification of successful English language learners. They took the test in different institutions such as the Golden Gate and the British Council. The data are then analyzed and interpreted in triangulation. The research findings showed that the engagement has shaped the success of the learners' language acquisition. The engagement comes in the forms of emotional, behavioral and cognitive ones. Such engagements take place from the silent period to communicative competence period of acquisition. It is further found out that to ensure the success of language acquisition, the three models of engagement have to be persistently and consistently practiced and developed.
\end{abstract}

Key words: cognitive engagement, behavioral engagement, emotional engagement, successful learners

Abstrak: Penelitian ini bertujuan untuk menyelidiki dan menggambarkan keterlibatan siswa terhadap proses pembelajaran bahasa. Penelitian ini kemudian memaparkan pengaruh keterlibatan siswa dalam kesuksesan pembelajaran bahasa. Penelitan ini menerapkan metode kualitatif. Wawancara 'semi- 
338 Celt: A Journal of Culture, English Language Teaching \& Literature, Volume 19, Number 2, December 2019, pp. 337 - 353

structured' diterapkan sebagai upaya untuk menguraikan tujuh pertanyaan inti dan pertanyaan lain untuk memperjelas ungkapan dari peserta wawancara. Peserta berasal dari Manado, Sulawesi Utara. Mereka adalah pelajar Bahasa Inggris yang memiliki skor TOEFL diatas 500 atau sederajat dengan score IELTS diatas 6, sebagai kualifikasi pelajar Bahasa Inggris yang baik. Mereka mengikuti ujian di institusi-institusi yang berbeda, seperti Golden Gate dan British Council. Data yang diperoleh kemudian dianalisis dan diinterpretasi dalam triangulasi. Hasil penelitian menunjukan bahwa keterlibatan siswa telah membentuk mereka sehingga berhasil dalam proses penyerapan bahasa. Keterlibatan yang dimaksud adalah keterlibatan secara emosional, sikap, dan keterlibatan secara kognitif. Keterlibatan tersebut terjadi sejak proses awal pelajar belajar Bahasa Inggris sampai pada keberhasilan dalam menggunakan Bahasa Inggris. Selanjutnya juga ditemukan, untuk menjadikan pelajar berhasil dalam proses penyerapan bahasa, tiga jenis keterlibatan yang disebutkan harus diterapkan dan dikembangkan scara terus menerus dan konsisten.

Kata kunci: keterlibatan secara kognitif, keterlibatan sikap, keterlibatan secara emosional, keberhasilan setiap pelajar

\section{INTRODUCTION}

Numerous studies have revealed that good language learners employed various strategies which contribute to their success in language learning. Learners tend to apply several strategies and find the most effective one for them to develop their language skills. However, although learning strategies have been recognized as a fundamental factor which facilitates language acquisition and also differentiates between good language learners and poorer ones, learning strategies are not the whole answer to making good language learners (Griffiths, 2015).

The other essential factor which defines a good language learner is the efficacy of strategies which depend on how learners engage with the learning goals, tasks, and contexts. Engagement is generally known as students' involvement in the classroom or what is so-called classroom engagement. It also has been defined as how interested students accomplish learning activities and how they connect to the peers, teachers, and institutions (Axelson \& Flick, 2010). Nevertheless, it does not solely occur in the classroom, yet it can also take place wherever and whenever learners are willing to engage themselves with language learning (Carroll, et al., 2019) 
Maru, M.G. and Pajow, C.P, Emotional, Behavioral, and Cognitive Engagement 339 Language Learning: The Experience of Successful Learners

Engagement in terms of language learning is examined as the way learners develop their communicative and academic skills through the meaningful practice that is continually conducted with a realistic comprehensible input and output (Nation \& Newton, 2009, cited in OgaBaldwin, 2019). A seminal study on learner engagement revealed that a good language learner has strong engagement, as it makes the learner successful in the language learning journey. Due to such study involved a narrative inquiry method, this study uses a different method with more amounts of participants to know how they engage with language learning.

In accordance with the engagement, many studies have been carried out, but they are more focused on classroom engagement (Ainley, 2012; Dao et al., 2019; Philp \& Duchesne, 2016). Few are conducted, concerning learners' engagement and its relevance to successful and effective language learning, particularly outside the classroom. The current study is deemed important to be conducted since the researcher believe that learners will experience more sense of learning when they directly practice outside the classroom setting. The other aspect that serves as the ground for the study is because engagement is believed as the key contributor to successful learning (Fredricks, Filsecker \& Lawson, 2016). Therefore, learners who are not engaged are less likely to be successful.

In other words, good language learners who are successful in learning a certain language have strong engagement with what they learn. As the ultimate goal of learning language is to reach communicative competence, those, who produce the language, use it appropriately, and then communicate it in a meaningful way, are regarded as successful language learners. The main aim of the current study is to investigate the successful learners' engagement in learning English as a foreign language. Realizing how pivotal engagement to the language learners, this study is conducted to answer the following research question: How did the learners behaviorally, emotionally, and cognitively engage with language learning for their successful acquisition?

\section{LITERATURE REVIEW}

Learner engagement categorizes into three parts which are behavioral, cognitive, and emotional (Fredericks et al., 2004). Behavioral engagement refers to the positive response and participation to academic tasks, length of time students spent to learn the target language, and their participation in academic and extracurricular activities. Cognitive engagement is concerned with self-regulated learning, strategies employed by the students, and their investment in learning. Emotional engagement means students' emotions and attitudes towards teachers, classmates, and school, as well as a sense of 
340 Celt: A Journal of Culture, English Language Teaching \& Literature, Volume 19, Number 2, December 2019, pp. 337 - 353

belonging at school. In this study, particularly, learner engagement will be related to learners' active approaches to the process of language learning.

The engagement does not only have an intriguing meaning focusing on the valuable involvement of students with the school, but also has different aspects, such as emotional, psychological, behavioral, and cognitive engagement (Skinner \& Pitzer, 2012). They categorized engagement into three levels started from the general to the specific one. In comparison to other kinds of engagement, they admitted that classroom engagement is the most engrossed one, as it is categorized as the most specific area of engagement. Classroom engagement is delineated as students' engagement to their academic work, signed with a positive attitude, for instance; enthusiastic, constructive, willing, emotionally positive, and cognitively focused participation. This engagement is recognized as critical for some reasons.

First, the process of acquiring knowledge and skill happens, only if the students are willing to create involvement active participation in the subject they learned. Second, a sense of academically competent emerges when students have high-quality of engagement so that they are more likely to perform greatly and connect with other peers as well as teachers. Another reason is because classroom engagement contributes to the academic development of students. It is believed as a part of the everyday resilience process and energetic resource to cope with the challenges, drawbacks, setbacks, and/or barriers in school. Effective coping will yield a durable longterm mindset to be motivated such students may have an autonomous learning style, and be more goal-oriented. Therefore, classroom engagement has an important role as a key player in developing academic assets which take place throughout the school year and over the entire educational career of students.

Moreover Finn \& Zimmer (2012) proposed that among the other terminologies which are different and complex to be differentiated, another model of engagement which frequently appears, are depicted as follows. First, academic engagement refers to the student's behavior towards the learning process, such as attentiveness and completing the classroom task or homework, or taking additional courses or academic extracurricular activities. The second is social engagement that refers to the extent to which the written or unwritten assignment is followed by the students, for instance, attending the class on time, having appropriate interaction with both teachers and students, and not exhibiting anti-social behavior such as withdrawal to themselves to participate in learning activities or disrupting other students' work.

Subsequently, a cognitive engagement which is indicated by students' behavior in inquiring a question to clarify the unclear explanations or 
Maru, M.G. and Pajow, C.P, Emotional, Behavioral, and Cognitive Engagement 341 Language Learning: The Experience of Successful Learners

concepts, reading and finding materials or sources beyond those required, using self-regulation and implementing other strategies to guide learning. Finally, an affective engagement is characterized by having a sense of belonging in school and realizing that the school activities are worth pursuing.

Among all of the classification of engagement that has been variously described, the three dimensions of engagement proposed by Fredericks et al. (2004) seems to be more appropriate in analyzing language learning, since the integration of cognitive, behavioral, and emotional engagement roughly covers the aspect of language learning which was researched the most, such as motivation, learning strategies, affective orientation, and cognitive traits (Lee \& Hsieh, 2019).

\section{METHOD}

This study employed a qualitative design. In order to obtain the data, a semi-structured interview was carried out consists of seven main questions and several follow-up questions, depending on the answer of the interviewees. The respondents or participants for this study are from Manado, North Sulawesi. They are learners whose score above 500 in TOEFL ITP or equivalence IELTS above 6.0 as the qualification of successful English language learners.

They took the test in differ institutions, such as the Golden Gate and the British Council. One of the participants took a TOEFL prediction on campus before finishing his undergraduate study. Student A and E followed the test in October 2019 and February 2019 respectively. While student C and D took the test in July 2019, student F took the test in May 2018. The remaining participant, Student B was tested in November 2017.

The participants were accessed by contacting them personally, and then conveyed what the researcher intends to conduct with them. When they agreed, the researcher arranged the appointments to interview them one by one.

Table 1:

Students' data and the detail of their TOEFL/IELTS score

\begin{tabular}{cccc}
\hline No & Students' Initial & Age & $\begin{array}{c}\text { TOEFL/IELTS } \\
\text { Score }\end{array}$ \\
\hline 1 & Student A & 24 & 520 \\
\hline 2 & Student B & 25 & 520 \\
\hline 3 & Student C & 22 & 6 \\
\hline 4 & Student D & 25 & 563 \\
\hline 5 & Student E & 29 & 517 \\
\hline 6 & Student F & 25 & 6.5 \\
\hline
\end{tabular}


The interview processes were conducted in the last week of November 2019, and during the data analysis, the interviewees were interviewed again if some clarifications were needed. The six participants have been interviewed about the engagement in learning English as a foreign language. Each participant was interviewed virtually, so that the interview processes were easily recorded. Table 1 presents the students' data.

The semi-structure interviews were conducted, following the interview protocol by (Creswell \& Creswell, 2018). After finishing the interview, the data were analyzed in three steps which are data organization, description, and interpretation (Best \& Kahn 2014). First of all, the data were compiled together and transcribed consecutively according to the interviewees' answers. Subsequently, the data were categorized into the table, by creating a separate column, consisting of the number of the questions. It will be more effortless to compare and analyze the data when it is organized in chronological order, based on the participants' answers.

Finally, at the last phase, the data were interpreted by coding them using the themes of the three model of engagement: behavioral, cognitive, and emotional engagement, following by the three stages of learning a language: the silent period, early production and experimentation, and continued language development and communicative competence.

\section{RESULTS AND DISCUSSIONS}

In this study, the learner engagement is investigated and detected by the enactment of a language learning process which is presented in three stages namely the silent period, early production and experimentation, and continued language development and communicative competence. By following methodologically these phases, the leaner engagement can be thoroughly and systematically portrayed in terms of having a picture of students' successful English language learning. The phases consist of the silent period, early production and experimentation, and continued language development and communicative competence:

\section{A. The Silent Period}

Silent period is defined as the earlier period of learners before they are able to communicate or use the language. It is similar to the infants when they first acquired a language by listening to the language that their family used. This concept is commonly known as second language acquisition. When 
Maru, M.G. and Pajow, C.P, Emotional, Behavioral, and Cognitive Engagement 343 Language Learning: The Experience of Successful Learners

someone learns a certain language, there will be time for them to silently listen or grasp the input from their surroundings (Krashen, 1982). Most of the participants conveyed, since they were in junior high school, they have had past habit they did unconsciously in terms of learning English. The activities had been done by watching the English shows either English movies, cartoons, and/or listening to the English song. These are admitted by the participant, as follows:

I always watched cartoons basically English cartoons like Fox Bunny and Mickey Mouse when I was childhood. Well, in those cartoons they speak a lot, so I intend to capture the vocabularies through their gestures. Cartoons actually are very active, unlike movies where they just stand and speak. In cartoons they performed what they were speaking, for example when they said "Let's run away!" and the next thing they do is run away. So, I kind of captured the vocabularies through the gestures which showed that run means walk very fast (Student D).

The answer above indicates that the learner had been attracted by English language since elementary school. As a result, the process of learning occurs unconsciously, which lead to the acquisition process. A similar activity was conducted by listening to the English song and simply imitate the words in the song. It is revealed in the following statement:

When I was junior high school, I basically loved listening and singing English song even though sometimes I didn't know what I was singing, I didn't know the lyric or the exact words and how to pronounce them. I just imitated it. Basically, I imitate the sound (Student B).

The learner's experience shows that the language is assimilated through the activity that they like the most. When they are interested in a certain activity, they tend to conduct it many times without realizing that they are learning something. Student F also acknowledge that he watched movies that he preferred several times. This evidence confirms that learners embark the learning process by exposing themselves to a massive amount of language input. The habits which they had been built since junior high school. It is is not a short time product.

In addition to this, learners do not only habituate themselves in watching and listening to the English, but some of whom learn English through a game, played when they were at school. They consider that playing a game intrigued and stimulated them to learn English, as mentioned by some learners below: 
344 Celt: A Journal of Culture, English Language Teaching \& Literature, Volume 19, Number 2, December 2019, pp. 337 - 353

Playing game is the only thing that I have been done to learn the language (Student C).

Yugio card actually popular in my childhood, so in order to know how to use this card, I need to learn what they meant in the text, so I read a lot of words in the dictionary (Student D).

Based on the statements above, the two learners admitted that their willingness in learning English is shaped by playing a game. The game encouraged them to follow the instruction or to understand what they should consecutively do and further learners are urged to find out the sentence meaning. At this point, it is obvious that since they were childhood, they actually played while learning English. The game that they played had helped learners to develop their English language literacy and use, even its simplest way; interacting with game instructions.

From all of the proposition above, it can be identified that at this period learners begins their interest to engage with the language by they found as interesting activities. As they enjoy the activities of watching, listening or playing a game when they were childhood, they actually exposed to English in every session of the game. Similarly, the establishment of the engagement can occur in a hobby such as singing as pointed out by the following respondent's expressions;

I think, this is related to my interest, because I like playing games since I was little, and I also enjoy watching English movies or listening to the English songs. I normally search for the lyric, so I think, I kind of absorb all the English phrases from those activities that I usually do, and I do it in my daily basis because I like doing it. It just happens every day (Student F).

It is clear that pleasant learning activities lead learners to have an awareness and enjoyment as well as enthusiasm for learning. The emotional aspect is taking a role. They deal with the language due to the feeling of like it. Therefore, these aspects are categorized within the emotional engagement. Additionally, starting a learning process with the activities that are very intriguing to the learners is deemed appropriate. By doing so, they will make themselves emotionally engaged to the learning process. The emotional engagement is recognized by learners' positive attitude and involvement to the learning experience, as in this context; learners are eager to learn English more. This seems to reveals that the emotional engagement occurs within the silent period. In terms of language acquisition process, this silent period should not be disregarded. This phase does not expect learners to produce a language instead it serves as learners' preparation to be ready in producing the language. Krashen (1982) puts forward, when learners have developed the 
Maru, M.G. and Pajow, C.P, Emotional, Behavioral, and Cognitive Engagement 345 Language Learning: The Experience of Successful Learners

competence of listening and understanding the language around them, the ability of speaking will follow afterwards.

\section{B. Early Production and Experimentation}

In comparison to the first stage, it is found that in the second phase learners showed, they have the three dimensions of engagement focused in this study. Firstly, in order to expand their vocabularies' knowledge, learners undertook various strategies and maximized every chance to learn new words. Being a strategic learner as well as performing their active involvement on learning activity indicates the cognitive engagement. It can be seen in the following responses:

When I was junior high school, I wrote down some vocabularies and have the notes. I memorized them every day, said the words many times, so I could memorize them in my mind" (Student A).

I learn new vocabulary by watching movies and take down note. I write every word that I considered unique and interesting, whether it is in the bus or from other books, or like everything that is new and interesting for me, especially when it comes to phrases, I would take that into my note (Student B).

The answers above display learners' desire and involvement in learning new vocabularies. Although the technique seems traditional, their contribution in learning new words is worth mentioning. They admitted that not every word had been written, yet only the specific words which they were curious about. Similarly, other participant also confirms that she executed the same strategy which was preparing a special note, and then writing down what she had found, as reported below:

Whenever I watch a movie, read a book or an article, I keep my note with me. If I find a new word, I usually search the meaning and write it down into my note. I don't look for the translation, but the meaning instead, so I can see the synonym and antonym of the word. That is the way I expand my vocabulary (Student F).

The learners strongly realize that they have to enrich their lexical resources, thus they are willing to continue learning new vocabularies. They utilize self-regulation strategy, which means they are cognitively engaged in the process of vocabulary learning. Another vocabulary learning strategy which nearly identical to the previous statement is demonstrated below:

I feel like every day I never feel enough about vocabulary, I'm not satisfied if I only know one word for one meaning. Finding the similar words that mean the same is really important. As a result, 
I can use the words creatively or be a creative language user. Besides, I also try defining the new words instead of translating. Definition is more than translation. If I only focus on translation, I only get a little, but in definition I may expand every word, so that I could get more, not only words but phrases as well (Student E).

Despite looking for the synonym and figuring out the definition rather than the translation are likely to become one of the most appropriate ways in expanding the vocabulary, not many learners are excited to do this. The strategies that have been done by learners represent cognitive engagement, showed by several indicators such as self-regulated learning or learning strategies implemented by them. Not only the cognitive engagement, but also the behavioral engagement is belonged to the learners, assessed by their effort and tenacity in learning English vocabulary, as emphasize herein:

I put a lot of effort for the vocabulary, because I think that the very basic part that we should have in mind. I can't speak or communicate if I don't have vocabulary bank in my mind (Student B).

The statement shows that learners are aware to the importance of expanding the vocabulary knowledge, which provide a noticeable impact to increase language proficiency. He actualizes his effort through rewriting technique, as it is believed useful in helping him to remember new words or phrases found, as mentioned below:

Firstly, I take new words and sentences into my vocabulary bank. Secondly, I love rewriting my note. I have two books with the exact same writing I just basically copy my writing from the one book to the other. That's the way where I can remember things quickly (Student B)

Throughout learners' journey in learning English, they confess, they have a great deal of experience when they are inappropriate in producing the language, for example when they mispronounce the words, make grammatical mistake, or produce the inaccurate translation. Although these cases happen frequently, it does not make them discourage to learn and elevate their skill in English, as mentioned below:

When I communicated with the foreigners, I misused certain words. I only translated the word literally. First, I felt I was correct, but then I realized the interlocutor did not understand my sentence. It became awkward and very embarrassing. This happened several times to me. But actually, I am thankful 
Maru, M.G. and Pajow, C.P, Emotional, Behavioral, and Cognitive Engagement 347 Language Learning: The Experience of Successful Learners

because I could experience such moment. I could learn from the mistake and know the correct one (Student E).

When it happened, the learner admitted that it was really unpleasant as well as unforgettable. He also felt ashamed. Nevertheless, the learner then stated, such experience did not cease him to learn more. Likewise, student B and $\mathrm{C}$ also point out that all of the mistakes are received as the chance and challenge to be better in the future. Another displeasing experience also occurred many times to English learners especially when they have to deal with sentence structure, as the acknowledgment below:

When I was asked: "What is the past tense of cut?" And I answered "cutted". I then realized I was wrong, and my friends actually mocked me. It's embarrassing, but when I got back home, I actually learned the related materials (Student D).

As the language learners, they realized that mistakes are inevitable, because it is believed as a part of learning. Interestingly, learners do not show disengagement in facing the unexpected situations. They tend to have a positive perspective instead, in which it connects to the emotional engagement. Therefore, learners' preference to react positively on their mistakes reveals that they are emotionally engaged to the language they learn.

\section{Continued Language Development and Communicative Competence}

In this phase, learners will continue to develop the process of learning, where it may last for an extended period of time. Hence, the engagement will be necessary until this stage. The following statement reports several ways that learners undertake in the current situation, and shows the evidence that they still engage to the learning activity until this period:

Whenever I really want to listen to the podcast, I would listen to it all day long, like 8 hours a day or as much time as I can. But the way I do it, I do not like sitting in front of the table and do listening, but I just play the podcast and I do my activities instead (Student B).

The participant is really engrossed in listening to the English podcasts, and it yields an advantage to him. His speaking ability is really great now. He admits that it because he had done the most exciting pronunciation practice about five months, as the preparation to embark his part time job with an Australian. He classified all of the Australia's podcasts and film documentaries and listen to them as much as he can every day. Firstly, he started with less complex accent videos, and then gradually continued with the more challenging one. 
Learner's strategy in listening extensively or listening to a wide range of English materials exposes themselves to a variety of language inputs which lead to the process of acquisition (Ivone \& Renandya, 2019). Extensive listening, therefore, involves cognitive and emotional engagement, which is displayed through learner's time investment, enthusiasm and enjoyment. They also demonstrate the way they practice English, even though they do not live in the English-speaking country, as stated below:

I talked to myself. It's like every time you remember the word or every time you recall a sentence from movie. If I consider that is pleasing to the ear then I would imitate it by talking to myself (Student B).

Sometimes when I listen to a certain speech in my first language, I try to instantly interpret or translate it at the moment. For example, when I watch a video where a public speaker is delivering a speech in L1, I directly follow with the English translation. This is actually challenge me to learn and practice English more (Student E).

The two techniques above are not exactly the same, yet they are almost similar. They do self-talk in order to practice their oral skill. With regard to this, student $\mathrm{F}$ also states that self-talk benefit to her IELTS preparation, particularly for speaking. She practiced to answer the speaking questions in front of the mirror. Self-talk is apparently peculiar; however, it is very beneficial, they confessed. Self-talk also refers to the self-regulated learning or learners regulate their own learning.

Turning to the learners' success, all of them acknowledge that they have one remarkable milestone, which they consider as an achievement in their English learning journey. It is described in the following statement:

Having experience to talk with the native speaker and became their interpreter became the most memorable experience in my journey of learning English (Student A).

Furthermore, four of the participants had ever been in the same event collaborating with the native speaker where they have a valuable chance to be an interpreter. Two of them achieved an outstanding score in TOEFL and IELTS official test which are 563 and 6.5 respectively. In addition, student $F$ mentions, having 7 in IELTS speaking test was beyond her expectation. The other competencies they have is proven by becoming a winner in University English Debating Competition (Student C), and participating to the National Debating Championship. Two of them had ever become the president of the prestigious campus organization namely English Debating Society. 
Maru, M.G. and Pajow, C.P, Emotional, Behavioral, and Cognitive Engagement 349 Language Learning: The Experience of Successful Learners

By having the evidence of learners' achievement, does not mean that it will be the final journey of their learning process. The participants report that nowadays, they still listen to the podcasts, English videos from YouTube, reading a lot of books, or even take one step ahead to learn idioms and phrases through the conversation in the movies. Learners do not conduct all of the activities simultaneously, yet every learner have their own preference which they consider as the most enjoyable and effective activities for them. As the learning process is a life-commitment, this phase should be a never-ending process.

The respondents' response as presented in the findings mark the answer to the objective of the study in investigating the form of language engagement that contribute to making of successful language learners in the context of English as Foreign language. The successful learners seem to experience, develop, and practice following emotional, behavior and cognitive engagement. The following is the discussion of each engagement. The following is the discussion of each engagement.

\section{Emotional engagement}

The earlier process of language learning undergone by learners portray that they are distant from disengagement, as they show their positive attitude and involvement by exceedingly watching and listening to the English cartoons or songs, or playing a childhood game with relates to English. Instead of having boredom in doing activities concerning English, learners show that they are interested in the target language. Hence, these activities and attitude indicate the emotional engagement of the learners.

The experience of having emotional engagement at the first period of the language development acquisition justifies the study of Ivone \& Renandya (2019) in which having a considerable amount of listening and viewing activities facilitate learners to the implicit learning and lead to the process of language acquisition. The silent period serves as learners' unconscious preparation before producing the language. Being engaged emotionally in this phase is important because it is impossible for learners to undertake a lot of listening and viewing activities without necessarily being interested to them first. In other words, if learners do not have emotional engagement, they are more likely to be unable to grasp the inputs before they are ready to use the language.

The emotional engagement can also be identified at the last stage of language learning acquisition. Despite this constitutes the final phase, the learners show that they still need to be emotionally engaged. It is characterized by their willingness to learn English consistently. It is noteworthy that they typically undertake an appealing activity and integrate it to the learning 
process. Integrating learners' interest with the English lesson is deemed as the most effective strategy to arouse their motivation as well as promote language acquisition (Pamuji, Waring \& Kurniawan, 2019). It implies that attempts related to the involvement of emotional drives to generate the interest in language can be forms of individual engagement in its particular context.

\section{Behavioral Engagement}

Behavioral engagement can be seen from their labors or active involvement in vocabulary learning. The learners perform their endeavor in enriching their vocabulary knowledge. Moreover, the research findings indicate that participants as learners found themselves make a lot of mistakes whether in pronunciation, sentence structure, or translation in their learning process. However, they are not concerned too much with such mistakes, rather than how they can learn from the mistakes. It agrees with the insights asserting that dealing with the mistakes positively may contribute to the successful learning, compared with having anxiety toward the mistakes (Kasbi \& Shirvan, 2017; Maru, Dukut \& Liando, 2018). Such attitude toward mistake shapes conducive behavioral engagement, and later succeed the language acquisition.

In that relevance, behavioral engagement is continuous. Learners normally conduct similar activities to those of the silent period. Watching movies, learning from YouTube channels, reading lots of English books, and playing beneficial games, are certainly the way to have maximal language input (Ivone \& Renandya, 2019; Renandya, W. A., Jacobs, G.M., Krashen, S., \& Ong, 2019). As EFL learners facing the circumstances that the learning process does not take place in English speaking country which may be lack of sense of language intuition and nuance as well daily context in its use, the participants show their endeavor to persistently behave in preserving good habits of language learning, such as investing a substantial amount of time in obtaining English inputs and practices.

\section{Cognitive Engagement}

The findings seemingly further illustrate that learners' strategies to elevate their English skill by investing a lot of time to practice are the form of the cognitive engagement. The cognitive engagement is defined by learners' self-regulated learning such as preparing a special note, jotting down the new words, memorizing and even rewriting, or finding the vocabularies' definition. Having a positive attitude and willingness in this study corroborates a finding that the higher proficiency learners who outperformed the lower ones, because they solved the learning obstacles than just solely overlooked at it by possessing an awareness to regulate their own learning processes. Further, not living in the English-speaking country does not delimitate learners to practice 
Maru, M.G. and Pajow, C.P, Emotional, Behavioral, and Cognitive Engagement 351 Language Learning: The Experience of Successful Learners

English. Talking to themselves is one of the ways they have been undertaking and considering effective.

Three of the participants strongly agree that talking to themselves is useful. Self-talk is a similar way conducted by a language learner which not only improve the pronunciation of uncommon words but also enhance learners' fluency when talking about the common topics in particular. Moreover, practicing through the collaboration with their friends, whether it is in between $1-2$ persons or in the organization can excel their ability to be more communicative. This represents cognitive engagement when learners have autonomy learning to practice and develop their English-speaking skill. Learners' engagement is performed through their consistency in seeking out the language input as well practice it in their real life.

Positive attitude, enthusiasm and motivation show that they are emotionally engaged. Last but not least, their effort and active involvement to commune with English language in the daily basis depict behavioral engagement. Without having an engagement, learners will be less likely to stand out and be successful in learning English.

\section{CONCLUSION}

To conclude, it is obvious from the findings that the respondents as successful learners enjoy their language acquisition after having encountered and undergone the learning process since the silent to communicative period. Within these periods, they build, develop and practice a strong engagement with English. The findings showed that learners' persistence and active participation to English every day refers to the behavioral engagement while the feeling of interest, pleasure, enthusiasm, and other positive traits indicate the emotional engagement.

The autonomous learning and learning strategies towards English represent the cognitive engagement. These engagements serve as the determinant factors for their successful language learning particularly English as foreign language. The earlier and more learners engage with language, the more advantage they gain. It fosters, maintains, and sharpens learners' skill.

Further, this study confirms and emphasizes that the proposition that language acquisition constitutes a process which undergoes phases and engagements. A successful learner is determined by the process. The engagement has also shaped the learners to encounter and to develop strategies and practices to guarantee the success of the language acquisition. The engagement itself constitutes a persistent and continuing process. It has to be the dominant color of the language learners particularly foreign learners. 
352 Celt: A Journal of Culture, English Language Teaching \& Literature, Volume 19, Number 2, December 2019, pp. 337 - 353

\section{REFERENCES}

Ainley M. (2012). Students' Interest and Engagement in Classroom Activities. In Christenson, S., Reschly, A., Wylie, C. (Ed.), Handbook of Research on Student Engagement. Springer, Boston, MA. https://doi.org/https://doi.org/10.1007/978-1-4614-2018-7 13.

Axelson, R., \& F. A. (2010). Defining student engagement. In Change: The Magazine of Higher Learning, 43 (pp. 38-43).

Best, J. W., \& Kahn, J. V. (2014). Research in Education (10th ed). Pearson Education Limited.

Carroll, M., Lindsey, S., Chaparro, M \& Winslow, B. (2019). An applied model of learner engagement and strategies for increasing learner engagement in the modern educational environment. In Interactive Learning Environments, 1 (15). https://doi.org/https://doi.org/10.1080/10494820.2019.1636083

Creswell, J. W., \& Creswell, J. D. (2018). Research Design Qualitative, Quantitative, and Mixed Methods Approaches. (5th ed.). SAGE.

Dao, P., Ngunyen, M.X.N.C., \& Iwashita, N. (2019). Teachers' perception of learner engagement in L2 classroom task-based interaction. In The Language Learning Journal, (pp. 1-14). https://doi.org/https://doi.org/10.1080/09571736.2019.1666908

Finn, J. D., \& Zimmer, K. (n.d.). Student engagement: What is it? Why does it matter? (\& C. W. S. L. Christenson, A. L. Reschly, Ed.). New York: Springer.

Fredericks, J., Blumenfeld, P., \& Paris, A. (2004). School engagement: Potential of the concept, state of evidence. In Review of Educational Research, 74(1), (pp. 59-105).

Fredricks, J., Filsecker, M \& Lawson, M. (2016). Student engagement, context, and adjustment: Addressing definitional, measurement, and methodological issues. In Learning and Instruction. 43 (pp. 1-4).

Griffiths, C. (2015). What have we learnt from 'good language learners'? ELT Journal, 69, 425-433.

Ivone, F. M., \& Renandya, W. A. (2019). Extensive Listening and Viewing in ELT. TEFLIN Journal, 302), 237-256.

Kasbi, S., \& Shirvan, M. E. (2017). Ecological understanding of foreign language speaking anxiety: emerging patterns and dynamic systems. Asian-Pacific Journal of Second and Foreign Language Education, 2(1), 
Maru, M.G. and Pajow, C.P, Emotional, Behavioral, and Cognitive Engagement 353 Language Learning: The Experience of Successful Learners

$1-20$.

Krashen, S, D. (1982). Principles and Practice in Second Language Acquisition. Oxford, Pergamon Press.

Lee, J. S., \& Hsieh, J. C. (2019). Affective variables and willingness to communicate of EFL learners in in-class, out-of-class, and digital contexts. System, 82, 63-73.

Maru, M. G., Dukut, E. M., \& Liando, N. (2018). Beyond Essay Structure: Competence and Literacy. Celt: A Journal of Culture, English Language Teaching \& Literature, 18(2), 282-296.

Nation, I. S. P, \& Newton, J. (2009). Teaching ESL/EFL listening and speaking. London: Routledge.

Oga-Baldwin, W. L. Q. (2019). Acting, thinking, feeling, making, collaborating: The engagement process in foreign language learning. System, 86. https://doi.org/doi: 10.1016/j.system.2019.102128

Pamuji, K. D., Waring, R., \& Kurniawan, E. (2019). EFL Teachers Experiences in Developing L2 Proficiency through Extensive Listening. TEFLIN Journal, 30(2), 257-273.

Philp, J., \& Duchesne, S. (2016). Exploring engagement in tasks in the language classroom. In Annual Review of Applied Linguistics, 36 (pp. 50-72).

Renandya, W. A., Jacobs, G.M., Krashen, S., \& Ong, C. H. M. (2019). The power of reading: Case histories of second and foreign language readers. Language and Language Teaching, 8(1), 10-14.

Skinner, E. A., \& Pitzer, J. R. (2012). Developmental dynamics of student engagement, coping, and everyday resilience. In \& C. W. S. L. Christenson, A. L. Reschly (Ed.), Handbook of research on student engagement (pp. 21-44). New York: Springer. 